
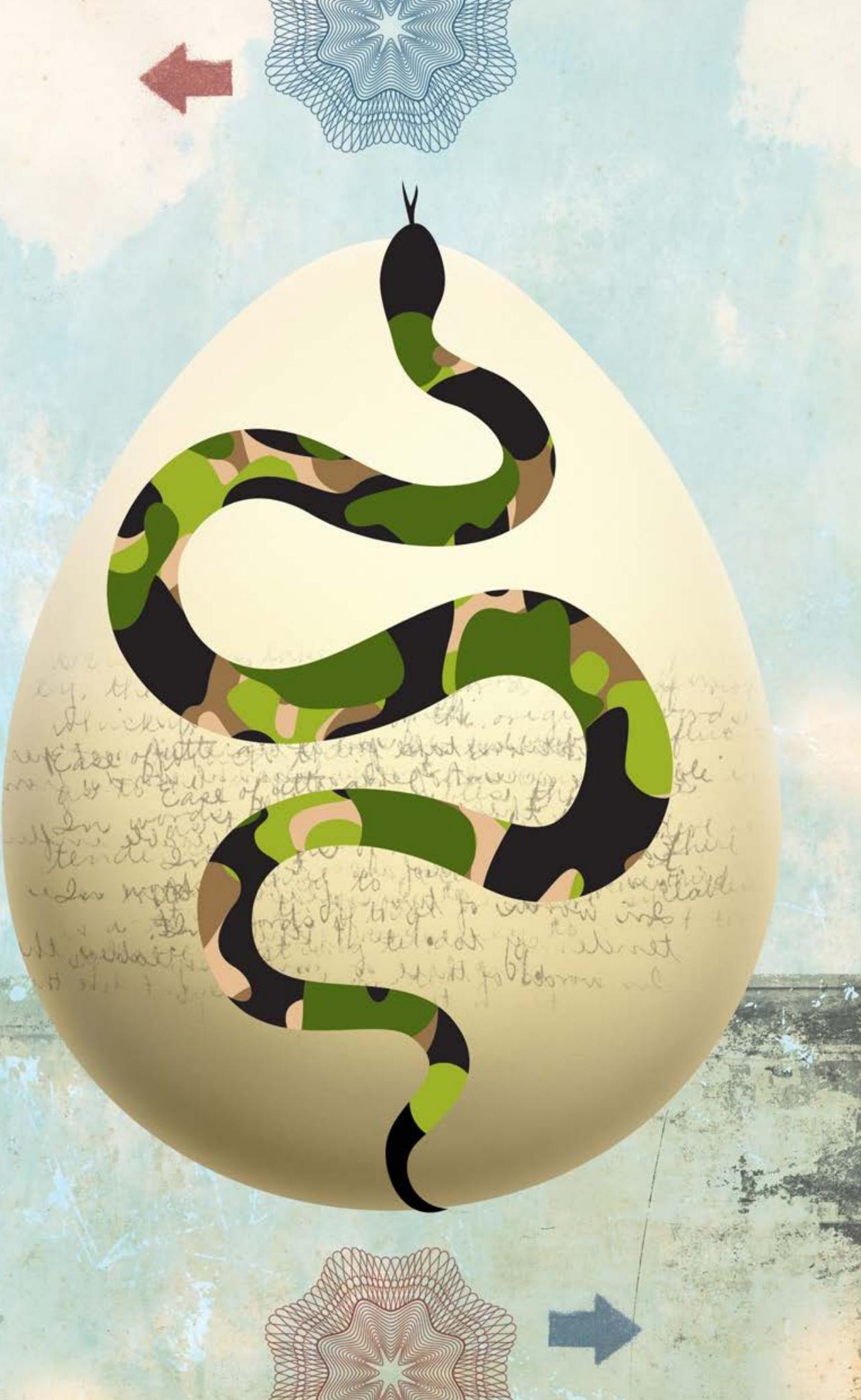


\section{O Fascismo no Brasil: o Ovo da Serpente Chocou}

\section{Fascism in Brazil: The Serpent's Egg Hars Been Hatched}

* Guilherme Simões Reis

** Giovanna Soares

\section{Resumo}

O ressurgimento do fascismo, juntamente com a ascensão do voto religioso, torna as disputas políticas no Brasil mais complexas do que a clássica clivagem socioeconômica direita $\mathrm{x}$ esquerda, predominante até as Jornadas de Junho de 2013. Por meio de discussão teórica sobre o fascismo e da análise de discurso de manifestantes nos atos pró-golpe entre 2013 e 2016, percebe-se um processo de fascistização no seio da sociedade brasileira. A análise do discurso do deputado Jair Bolsonaro indica que ele se credencia como possível líder fascista.

Palavras-chave: Fascismo; Ideologia; Voto religioso; Conservadorismo; Manifestações.

\begin{abstract}
The new rise of fascism, together with the emergence of religious vote, makes political struggle more complex than classic socioeconomic cleavage right vs. left, prevailing until June 2013 uprising. By theoretically analysing activists' speeches in demonstrations between 2013 and 2016 in support of the coup we notice a process of fascistization inside Brazilian society. An analysis of MP Jair Bolsonaro's speech shows that he is qualified as a possible fascist leader.
\end{abstract}

Keywords: Fascism; Ideology; Religious vote; Conservatism; Demonstrations.

\footnotetext{
* Guilherme Simões Reis é professor da Escola de Ciência Política da UNIRIO, no mestrado e no bacharelado em Ciência Política e no Mestrado em Direito com ênfase em políticas públicas. É doutor em Ciência Política pelo IESP-UERJ e foi pesquisador visitante na Universidade de Frankfurt.

E-mail: guilherme.s.reis@unirio.br

** Giovanna Soares é cientista política formada na UNIRIO e pesquisadora do projeto "Quem dá golpe de Estado em quem?: Banco de dados sobre o perfil dos governos derrubados e emergentes."

E-mail:gmatias.gs@gmail.com
} 


\section{Introdução}

A disputa política brasileira, no plano federal, teve na polarização entre Partido dos Trabalhadores (PT), pela esquerda, e Partido da Social Democracia Brasileira (PSDB), pela direita, seu aspecto central desde a eleição de 1994. As chamadas Jornadas de Junho de 2013, como gigantescas mobilizações de rua, destoaram das disputas institucionais, que, mesmo que com contradições, claramente estavam delimitadas no eixo direitaesquerda. Se foram iniciadas por movimentos mais organizados, como o Movimento Passe Livre (MPL), logo as Jornadas sofreram um "desbordamento societário", com "movimentos derivados" aproveitando "espaços abertos pelas mobilizações iniciais, sem, contudo, manter laços fortes, enquadramentos sociopolíticos, formas organizativas, referências ideológicas e repertórios de mobilização que os una ao MPL e/ou a outros iniciadores" (Bringel, 2013: 45).

As interpretações sobre aqueles eventos dramáticos são variadas, indo desde os que, enxergando uma "situação revolucionária", apontam virtudes, de atores insubmissos que não protestam apenas na penúria mas por quererem melhorias contínuas, representando uma inovação não compreendida pelo engessamento petista (Cocco e Cava, 2013), até aqueles que veem o espalhamento do fascismo para além dos pequenos grupelhos assumidamente dessa posição no início das manifestações por passe livre, em derrota da esquerda na disputa pelo"significado das ruas", em grande parte por conta da atuação enviesada da mídia e da criminalização da política por parte do Judiciário (Santos, F., 2013).

Mesmo o tema específico da violência, em si, é tratado de forma muito variada. Para Cardoso (2013), foi direcionada particularmente aos símbolos dos serviços públicos ineficientes e do déficit do direito à cidade, como os transportes, sendo assim, portanto, perfeitamente compreensível. Para Cocco e Cava (2013), os blackblocks são "a expressão mais potente do movimento", tendo a virtude de atrair jovens militantes. Para Bringel (2013), a violência é a forma característica de os black-blocks se expressarem, mas é uma, entre outras, das formas pelas quais se expressa o "retorno do conflito", este sendo uma das características mais importantes do novo ciclo de ação coletiva no Brasil. Santos, W. G. (2013), por sua vez, em posição destoante, considera os black-blocks "parasitas dos movimentos sociais", incapazes de organizar algo construtivo, que se infiltram nas atividades e organizações de construtores sociais para lhes sugar a fama, a energia ou os propósitos.

O certo é que aquelas Jornadas de Junho não foram um fenômeno homogêneo, reunindo grupos tão díspares como esses anarquistas black-blocks, neoliberais criminalizadores da política, movimentos sociais organizados, pessoas despolitizadas ansiosas por se engajar, militantes de partidos de esquerda e, conforme detalha Amaral (2016), organizações libertárias de direita financiadas por capital internacional e por frações do empresariado brasileiro. Diferentes grupos tentaram direcionar aquela potência, com claro fracasso da esquerda organizada - vítima de violenta reação 
antipartido - e com a significativa, mas não decisiva, vantagem para a direita, insuflada com tendenciosa e constante mobilização via mídia hegemônica - a interpretação aqui tem, portanto, proximidades com a apresentada por Santos. F. (2013). Seguiram-se manifestações de menor porte, em que a direita e a esquerda não mais se misturaram. O caráter das mobilizações reacionárias, ainda que heterogêneas, suscita, entre outros, este debate: há um ressurgimento do fascismo no Brasil?

Desde a redemocratização, a disputa política no Brasil podia ser entendida em uma única clivagem, baseada na disputa socioeconômica, e a incorporação das pautas identitárias pela esquerda ocorria dentro desse mesmo eixo. Paralelamente, havia moderação na questão econômica, um pouco como no modelo de Kitschelt (1994) sobre a "social-democracia". A direita, mesmo com a participação de setores "atrasados" e oligárquicos, era liderada pelo "moderno" PSDB, partido representante da ideologia liberal, não identificado com o conservadorismo de costumes.

A disputa política no país, no entanto, tornou-se mais complexa a partir do momento em que ao menos dois fenômenos emergiram, fora do modelo mais "clássico" de disputa capital x trabalho: 1) o fortalecimento do voto religioso, entendido como hostil à laicidade do Estado e ultraconservador quanto aos costumes (podendo estar ou não à direita na questão econômica, como fica evidente, por exemplo, pelo apoio da Igreja Universal às políticas sociais até aderir ao golpe de Estado de 2016'1); 2) e o estouro, na sociedade, de uma política virulenta contra a esquerda (especialmente, mas não apenas, contra o PT), apoiadora de soluções autoritárias, baseada em ódio, que, conforme será argumentado neste artigo, pode ser entendida como fascista.

A Frente Parlamentar Evangélica tinha em 2016 seu maior contingente, 92, entre deputados e senadores, o que significa muito mais membros do que na legislatura anterior, quando eram 78 deputados e três senadores, o maior número até então. Em 2016, a frente apoiou o golpe de Estado e um de seus membros, o deputado Eduardo Cunha, presidia a Câmara e foi figura central para o processo de impeachment. Parlamentares conservadores católicos não fazem parte da FPE, mas votam de modo parecido, o que significa que o peso da política religiosa conservadora é ainda maior. O crescimento da bancada evangélica tem sido contínuo, todavia, segundo Cunha (2015), desde sua origem, em 1986, mesmo nunca tendo"uma pauta progressista, ou de esquerda", seus representantes também não eram identificados como "conservadores do ponto de vista sociopolítico e econômico", adotando em bloco posicionamentos reacionários apenas mais recentemente:

Seus projetos raramente interferiam na ordem social: revertiam-se em "praças da Bíblia", criação de feriados para concorrer com os católicos, benefícios para templos. O perfil dos partidos aos quais a maioria dos políticos evangélicos estava afiliada refletia isso bem com recorrentes casos de fisiologismo. Mais recentemente é o forte tradicionalismo moral que tem marcado a atuação da Frente Parlamentar Evangélica, que trouxe para si o mandato da defesa da família e da moral cristã contra a plataforma dos movimentos feministas e de homossexuais e dos grupos de 
direitos humanos, valendo-se de alianças até mesmo com parlamentares católicos, diálogo historicamente impensável no campo eclesiástico (Cunha, 2015).

Desde o golpe de 2016, pode-se dizer que o Brasil tem um governo autoritário e movido por pautas reacionárias, com um Estado crescentemente violento e descompromissado com os direitos e garantias; mas não é um governo ou um Estado fascista. Na sociedade, no entanto, o fascismo já é perceptível, podendo inclusive tornar-se uma força eleitoral relevante, a julgar pela repercussão pública do nome do deputado federal Jair Bolsonaro, abertamente um defensor da ditadura militar, da tortura, da homofobia e de políticas de segurança pública repressivas.

As fronteiras entre os diferentes grupos conservadores não é tão clara. O candidato do PSDB à Presidência em 2010, José Serra, por exemplo, afastou o partido de sua histórica posição laica ao tentar enfraquecer a adversária Dilma Rousseff associando-a ao aborto e afirmando ser contrário a ele devido a "seus valores cristãos". Por outro lado, o mencionado Bolsonaro, provável representante do fascismo na eleição presidencial prevista para 2018, é filiado ao Partido Social Cristão, uma das agremiações com mais representantes na Frente Parlamentar Evangélica, e incluiu em seu repertório como modelo de comportamento exemplar, além da heterossexualidade, da disciplina, da virilidade e do não uso de drogas, os valores cristãos.

O peso do fascismo na política parlamentar e sua presença no Estado não são fáceis de se mensurar, pois a adoção de um discurso dessa natureza em geral é pontual e não tão evidente como no caso de Bolsonaro. Sua presença na sociedade, no entanto, tornou-se mais visível nos últimos anos. Nas seções seguintes deste artigo será discutido o que se entende, aqui, por fascismo, e serão apresentados elementos indicativos da fascistização de parte da sociedade brasileira, com ênfase nos protestos golpistas e no discurso do principal nome a canalizar tal posicionamento, o deputado federal Jair Bolsonaro.

\section{O que é o fascismo?}

Santos e Szwako (2016: 119) identificam que o fascismo cresce nas classes médias, sendo "alimentado não somente pela crise econômica, mas também pelo Judiciário e por mídias hegemônicas, [e que ele] é realidade que julgamos imprescindível conhecer e combater". Esse ponto é relevante e será retomado mais adiante, na discussão sobre a propaganda no fascismo. Os autores complementam que "A mobilização verde e amarelo que ganhou as ruas nos meses de março, abril e agosto de 2015 soube se apropriar de um dos principais legados de 2013", e que "Aos gritos de'Fora Dilma' e'Fora PT', uma massa de verve fascista foi alimentada por movimentos de direita que, como se sabe hoje, foram e são ligados a partidos golpistas e a grupos ultraconservadores estadunidenses." A leitura até aqui é semelhante à realizada neste artigo, mas destoa na definição que os autores apresentam sobre o que seria o fascismo: 
Uma pergunta aqui se impõe: por que denominar de fascista uma multidão tão vasta e heterogênea? Designamos-lhe como tal devido à sua incapacidade de reconhecer como legítima uma pluralidade de interesses e visões de mundo que é constitutiva e, sobretudo, distintiva da democracia em sociedades complexas. Negar tal pluralidade corresponde, nos discursos e protestos conservadores de 2015 analisados alhures, a negar a legitimidade do conflito e da necessária institucionalização dos conflitos - sem a qual não há convivência democrática e civilizada entre diversos e divergentes interesses e visões de mundo (Santos e Szwako, 2016: 119).

Em trabalho anterior, Santos, F. (2013) destacou alguns elementos comuns ao fascismo conforme definição que será trabalhada neste artigo - repulsa pelos partidos, autoritarismo, intolerância, recurso à violência - mas, de modo semelhante a Hannah Arendt, conforme também será abordado mais adiante, parte de definição que não distingue divergências programáticas fundamentais entre visões radicais situadas em espectros ideológicos muito distintos:

Uso os termos "fascismo" e "protofascismo" de maneira assumidamente pouco rigorosa. Com eles, quero designar uma atitude política autoritária cuja essência consiste em não reconhecer a pluralidade de interesses e opiniões existentes na sociedade como algo legítimo. A princípio, o alvo da atitude fascista, como na experiência italiana e alemã do período que antecede a Segunda Guerra Mundial, são os partidos e o governo representativo. A pluralidade partidária, baseada no voto popular, é vista como um mal a ser extirpado, posto que baseado na delegação de poder feita de forma equivocada por seres inferiores, o povo. A apologia da democracia direta e da imposição da vontade via manifestações violentas e depredações é o corolário comportamental dessa atitude. Depredações, ataques ao comércio e prédios públicos são as formas mais patológicas de tal comportamento (Santos, F., 2013: 18).

A rejeição a essa definição, portanto, deve-se ao fato de que nem toda negação violenta da pluralidade é fascista. Fascismo tem sim, entre suas características, a violência e a intolerância, porém é mais do que isso. É sustentado neste artigo que o fascismo cresce no Brasil não apenas pela forma cada vez mais conflituosa das relações políticas, mas fundamentalmente por uma questão política substantiva, que inclui como é formulado o discurso. A visão de fascismo aqui adotada remete-se à apresentada em outro trabalho:

O fascismo pode ser entendido como uma variação do conservadorismo, especialmente do conservadorismo romântico. Também dá maior peso à comunidade do que ao indivíduo - sendo o movimento fascista a cola de unificação da sociedade desarticulada por liberais e socialistas, que não preservam a tradição - e dá enorme valor à hierarquia: o líder, o Führer, o duce concentra enormes poderes, a cultura da obediência é fortemente cultivada e os ritos e a simbologia são cruciais. Quer restaurar um passado glorioso, autêntico, fortemente vinculado às tradições do povo, como os conservadores românticos, mas se diferencia deles por uma característica bastante central: identifica um ou mais grupos inimigos (podem ser judeus, islâmicos, negros, imigrantes, ciganos, socialistas etc.) como responsáveis por essa degradação e visa a enfrentá-los violentamente até sua destruição, para que então seja possível o retorno ao passado idealizado (Reis, 2017: 129). 
Carone (2002), em sua discussão sobre estudos de frankfurtianos, como Theodor Adorno, sobre o fascismo estadunidense e sua semelhança com outros fascismos, como o nazismo germânico, dá outros passos importantes para se traçar uma definição mais completa do que é o fenômeno, salvaguardadas as diferenças de cada caso e de cada país. Carone (2002: 196) nota que "a discriminação enquanto comportamento político fascista estaria muito mais na dependência da psicologia do discriminador do que das características dos alvos da discriminação". A definição de inimigos, como bodes-expiatórios irracionalmente apontados como culpados por todos os males, que devem ser destruídos, é, como apontado anteriormente, central, e faz parte da estratégia desumanizá-los:

Mas quem eram os inimigos? Onde se escondiam? Onde conspiravam? Como deviam ser enfrentados? Eles eram apresentados como traidores, vilões, arruaceiros e assassinos. $O$ inimigo não só era identificado com o submundo criminoso mas também como alguém que agia impunemente e sob a proteção política do país. Por conseguinte, o único meio de combatê-los seria o de tomar a lei nas próprias mãos (Carone, 2002: 212).

Entre os inimigos, evidentemente, sempre está a esquerda, mas também toda política organizada institucionalmente, vista como precisando ser rompida.Como mobiliza emocional e não racionalmente os simpatizantes, tende a um forte antiintelectualismo, a uma rejeição ao acumulado conhecimento acadêmico, que refuta suas teses: "comunistas, esquerdistas, intelectuais antipatrióticos" (Carone, 2002: 204).

Também fundamental em um movimento fascista é o personalismo, o que Losurdo (2004b) destaca como estratégia exitosa de defesa do status quo e da despolitização por parte da direita em geral, especialmente pela tradição liberal. No fascismo, o personalismo se dá via idealização de líderes, em discurso repetitivo. Analisando o caso estadunidense, Carone (2002: 211-212) nota que o líder fascista deve ser visto como um homem comum do povo, mas particularmente virtuoso:

De modo diferente dos idealistas que sacrificam o seu conforto em prol de um propósito social nobre, o agitador vem do povo e se apresenta como alguém quase indistinguível da grande massa de cidadãos norte-americanos. Não deixa de frisar nas entrelinhas, no entanto, que é um esposo modelo, um bom e solícito pai para os seus filhos, com problemas financeiros e de saúde, de modo a diminuir a distância e a criar familiaridade e intimidade com os seus ouvintes.

A idealização dos líderes ocorre em contraposição aos out-groups sobre os quais recai uma "suspeita paranoica"; enquanto os primeiros são "um homem solitário, espontâneo, corajoso e íntegro", "inocente perseguido", "homem carismático" etc, os inimigos são representados como "parasitas da economia", "homens sem pátria e sem patriotismo", "conspiradores" (Carone, 2002). O perseguido é apresentado como perseguidor: "O artifício do inocente perseguido serve a um duplo propósito. Primeiro, interpretava o perigo para o líder como um perigo para todos e racionalizar a agressividade sob o disfarce da autodefesa." (Carone, 2002: 201). O argumento não segue a lógica, importando que atinja psicologicamente o alvo: 
Isso quer dizer que a sua linguagem primou mais pelos aspectos psicológicos do que lógicos das asserções. De um ponto de vista meramente lógico ou objetivo elas poderiam ser consideradas absurdas ou pouco consistentes. Seria um engano supor, entretanto, que a falta de lógica de suas asserções fosse devida a uma falta de capacidade intelectual. Na verdade, essa falta de objetividade ou de lógica obedeceu ao primado do subjetivo sobre o objetivo: ele queria mobilizar a sua audiência, isto é, os temores, os rancores, os ressentimentos e os sentimentos de desamparo na vida social. Essas características de um discurso calculado racionalmente para provocar efeitos irracionais são próprias da propaganda fascista e antissemítica em qualquer parte do mundo (Carone, 2002: 204).

Essa audiência seria recrutada, segundo Arendt (1998: 361-362), primordialmente entre as camadas da sociedade que ela denomina "massas", que, além de numerosas, são desorganizadas politicamente, constituindo "a maioria das pessoas neutras e politicamente indiferentes". Em sua maioria nunca antes participaram da política e não tiveram a atenção dos partidos tradicionais, que as consideraram "demasiado apáticas ou estúpidas para Ihes merecerem a atenção". O movimento fascista aproveitaria essa brecha para atraí-las. Sua aversão aos partidos tradicionais e à institucionalidade estabelecida, é mencionada também por Arendt (1998: 265) ao tratar da Europa:

Além disso, [os partidos] haviam perdido, sem que percebessem, aqueles simpatizantes neutros que nunca se haviam interessado por política por acharem que os partidos existiam para cuidar dos seus [próprios] interesses. Assim, o primeiro sintoma do colapso do sistema partidário continental [europeu] não foi a deserção dos antigos membros do partido, mas o insucesso em recrutar membros dentre a geração mais jovem e a perda do consentimento e apoio silencioso das massas desorganizadas, que subitamente deixavam de lado a apatia e marchavam para onde vissem oportunidade de expressar sua violenta oposição. [...] as maiorias adormecidas, que existiam por trás de todos os partidos, [foram transformadas] numa grande massa desorganizada e desestruturada de indivíduos furiosos que nada tinham em comum exceto a vaga noção deque as esperanças partidárias eram vãs; que, consequentemente, os mais respeitados, eloquentes e representativos membros da comunidade eram uns néscios e que as autoridades constituídas eram não apenas perniciosas mas também obtusas e desonestas.

Bringel (2013) seguramente não vê a situação dos levantes de 2013, em que também muitos jovens tiveram seu "batismo político", de modo similar ao diagnóstico de Arendt sobre a ascensão de massas suscetíveis ao totalitarismo na Europa do seu tempo. Ainda assim, a descrição que ele faz deixa margem à interpretação de que havia, sim, uma insatisfação difusa de jovens sem experiência política que poderiam, sim, ser seduzidos por soluções fora do sistema político tradicional não necessariamente progressistas, tal como na narrativa de Arendt:

[...] associam sua insatisfação a uma rejeição aos sistemas políticos, aos partidos tradicionais e às formas convencionais de organização política (inclusive a certos movimentos sociais e sindicais hierarquizados e ligados ao aparelho estatal). Querem participar da vida política, mas não encontram canais adequados. Para muitos deles, conselhos, fóruns e espaços institucionalizados não são suficientes e mostraram seus limites nos últimos anos. Antes de criticar os jovens por isso, deveríamos nos 
perguntar o que (e por que) não funciona. E aproveitar a oportunidade de ruptura da apatia e queda do muro de silêncio para a conquista de direitos e avanços na transformação social (Bringel, 2013: 46).

Nesse processo, uma das questões-chave enfrentadas pelos atores sociais e políticos que lutam pela emancipação e pela justiça social continua a ser a seguinte: como canalizar a indignação em movimento social transformador? A resposta não é fácil, dada a multiplicidade de perspectivas, significados e possibilidades abertas pelas movimentações recentes. O que talvez, sim, tenha ficado claro, ao reintroduzir a conflitualidade na cena política, são os limites de uma política de "conciliação nacional" a partir da qual o governo, por meio de amplas coalizões, busca agradar a forças e atores antagônicos em uma sociedade marcadamente desigual (Bringel, 2013: 51).

A preocupação central de Arendt (1998), ao menos na parte final do seu famoso livro "Origens do totalitarismo", é com o totalitarismo e não como fascismo - e a categoria "totalitarismo", polissêmica, é empregada por ela com imprecisões históricas e viés ideológico (movido pela guerra fria), forçando semelhanças entre o estalinismo e o nazismo e excluindo casos com vista a fortalecer o argumento (Losurdo, 2004a). A aproximação realizada entre a Alemanha nazista e a União Soviética deliberadamente abre mão do aprofundamento da comparação político-programática entre os dois casos, considerando ambos semelhantes em seu modus operandi e consequências.

Ainda assim, com atenção a todos esses problemas de sua argumentação, algumas de suas reflexões oferecem insights para pensar em como se disseminou e pode se espalhar a faísca do fascismo, naquele tempo e hoje. A aversão aos partidos estabelecidos não se dá pela crítica aprofundada a qualquer um deles - mas pela rejeição passional a todos, especialmente aos da esquerda - e nem por meio da criação de um projeto inovador consistente, mas pela postura violenta de repúdio e pela busca de um líder que canalize tal sentimento. A propaganda é fundamental na atração e mobilização dessas massas e, renegando a história oficial como uma fraude e apresentando teorias conspiratórias não observáveis, assim as alcançava:

[...] gigantescas mentiras e monstruosas falsidades viessem a transformar-se em fatos incontestes, de que o homem pudesse ter a liberdade de mudar à vontade o seu passado, e de que a diferença entre a verdade e a mentira pudesse deixar de ser objetiva e passasse a ser apenas uma questão de poder e esperteza, de pressão e de repetição infinita (Arendt, 1998: 383).

Características distintivas do caso brasileiro são a provável concentração em camadas mais abastadas da população entre as adesões ao movimento, ao menos neste primeiro instante, talvez por conta da efetiva melhoria de vida proporcionada pelas políticas sociais recentemente implementadas pela esquerda no poder, e a questão da internet e das redes sociais, que descentralizam a propaganda fascista, ainda que tenham suporte irresponsável da mídia hegemônica tradicional, que o alimenta como efeito colateral da perseguição à esquerda. ${ }^{2}$ 


\section{O pós-junho de 2013: um resumo das manifestações e do fascismo ali presente}

O ressurgimento do fascismo no Brasil $^{3}$ pode ser identificado de forma mais visível após o enfraquecimento da imagem de Dilma Rousseff e do Partido dos Trabalhadores (PT) com a realização de atos gigantescos em junho de 2013, que caracterizou um momento de súbita manifestação de insatisfação da sociedade com seus governantes. Tratava-se, inicialmente, de atos com pautas prioritariamente progressistas e com manifestantes de perfil heterogêneo. Entretanto, a sucessão de protestos foi dividindo os grupos entre defensores da democracia e militantes de esquerda em um tipo de evento, e reacionários e golpistas em outro, o qual tendeu a predominar nos anos subsequentes, até o golpe de Estado de 2016, quando, inclusive, as manifestações de rua da direita, supostamente movidas pelo repúdio à corrupção, deixaram de ocorrer, evidenciando que o único objetivo dos organizadores era tirar o PT do poder.

O pontapé inicial desse ativismo foi a proposta de aumento da tarifa de ônibus em alguns estados em vinte centavos, que gerou manifestações com números significativos no dia 6 de junho de 2013. Os atos em São Paulo, Rio de Janeiro, Brasília e Belo Horizonte totalizaram cerca de 85 mil pessoas. Em São Paulo, os policiais reagiram de forma desproporcional ao lançar bombas de gás e spray de pimenta nos manifestantes na tentativa de impedi-los de chegar à Avenida Paulista. A força policial tinha o amparo dos grandes veículos de comunicação, que endossavam a necessidade de repressão aos chamados "vândalos" ou "baderneiros". Como reação, os manifestantes atiraram pedras, picharam ônibus e incendiaram lixo.

Como consequência, o protesto seguinte, do dia 17 de junho de 2013, adicionou à sua pauta a reivindicação por menos violência e repressão policial. Com quase 300 mil pessoas pelo país inteiro, era inevitável que se multiplicassem os cartazes e os pedidos de maiores investimentos na saúde, educação, transporte, que se opunham, simultaneamente, ao investimento feito para a realização da Copa das Confederações de futebol. Os manifestantes também levantavam bandeiras contra o preconceito e reivindicavam maior transparência dos governos. Houve choque entre polícia e manifestantes radicais - os black-blocks -, que se expandiu, com a repressão vitimando também os que protestavam pacificamente. No Rio de Janeiro, um grupo tentou invadir a Assembleia Legislativa do Estado (Alerj), jogando pedras, coquetéis molotov, incendiando carros e depredando três agências bancárias.

Já no dia 26 de junho de 2013, 388 cidades do Brasil fizeram história ao juntar cerca de 1,5 milhão de pessoas nas ruas, reivindicando não só as pautas do dia 17 como a não-aprovação da PEC 37 (proposta que daria exclusividade de poder de investigação criminal para as polícias federal e civis, retirando tal prerrogativa do Ministério Público e de outros órgãos), a rejeição ao projeto que propõe tratamento médico para a "cura" da homossexualidade (conhecido como "cura gay") e a melhoria nas universidades. Houve conflito entre manifestantes e a polícia em boa parte das cidades. Desta vez, 
no entanto, o repúdio à política e aos políticos ficou mais claro, com nomes expostos em cartazes, como por exemplo na inscrição "Mais felicidade, menos Feliciano!" (referindo-se a Marco Feliciano, deputado federal do estado de São Paulo e integrante da bancada evangélica), e com os conflitos internos (principalmente em São Paulo) gerados pela rejeição e opressão de manifestantes apartidários a qualquer militante que aparecesse carregando bandeiras de partidos - principalmente do Partido dos Trabalhadores. Esse é o sinal de que, mesmo com propostas iniciais mais universais, a heterogeneidade do movimento começava a ficar evidente pela diversidade de reivindicações. Estas, mesmo em sua grande maioria ligadas principalmente a problemas de responsabilidade estadual e municipal, acabavam por respingar diretamente na presidenta Dilma Rousseff. A Copa das Confederações e as eleições em 2014 reforçavam esse quadro.

No início de 2014, protestos em São Paulo e mais 50 cidades defendiam o direito de se expressar e exibiam o desejo por mais investimento na segurança pública e pelo aumento do número de escolas. Grupos setoriais, como os metalúrgicos e professores, reivindicavam melhores salários, e membros do Movimento dos Trabalhadores Sem-Teto (MTST) faziam suas demandas por mais moradias. Houve conflitos entre manifestantes e policiais naquele ato e também nos que aconteceram na semana de 12 a 18 de junho de 2014, quando os presentes se posicionavam contrários à realização da Copa do Mundo, considerando que a alta quantia de dinheiro investido deveria ter sido utilizada em melhorias na saúde, educação e cultura. Cartazes traziam frases como: "Gari vale mais que o Neymar"; "Copa sem o povo, tô na rua de novo"; "Copa para quem?"; "Fifa, go home!". O grito de ordem "Não vai ter Copa!" sintetizava a insatisfação.

Logo após as eleições, ficara subentendido que a apertada vitória de Dilma Rousseff com 51,64\% dos votos significava uma divisão de opiniões da sociedade brasileira e prenunciava um difícil governo para a presidenta. A entrada do $13^{\circ}$ ano de governo petista trouxe protestos voltados especificamente contra ele, inflamados pela continuidade da Operação Lava-Jato, com a descoberta e ampla divulgação espetacularizada de cada vez mais casos de corrupção, além da acusação de fraude dos vitoriosos por parte do candidato derrotado na eleição presidencial, Aécio Neves, do PSDB.

No dia 12 de abril de 2015, cerca de 534 mil pessoas em 24 estados e no Distrito Federal manifestaram repúdio aos políticos devido aos casos de desvio de verba pública: era frequente nos cartazes a frase imperativa "Fora CorruPTos!", relacionando a corrupção à imagem de Dilma e Lula e ao Partido dos Trabalhadores em geral. Reivindicavam como solução a cassação da presidenta, por meio de impeachment (mesmo que não houvesse qualquer indício de suposto crime por parte da mandatária) ou a renúncia, para execução de novas eleições.

Tal como no fascismo, a aversão aos partidos estabelecidos se dá sem crítica aprofundada e de modo passional, direcionando-se a todos mas com ênfase contra a esquerda. A fragilidade das bandeiras evidencia a falta de projeto inovador consistente, 
e é constante a busca de um líder que canalize esse repúdio violento - Bolsonaro e o juiz Sérgio Moro, responsável pela Operação Lava-Jato, aparecem como ídolos e popstars, admirados por não pertencerem ao mainstream político, visto como corrupto e sem energia para tomar as medidas duras necessárias. A propaganda é fundamental na atração e mobilização dessas massas e, renegando a história oficial como uma fraude e apresentando teorias conspiratórias não observáveis, que não obedecem à lógica mas têm forte apelo emocional, apresentam o PT como organização criminosa, envolvida em terrorismo e em articulações internacionais para implantar o comunismo, além de coordenação de esquemas inéditos de corrupção ${ }^{4}$.

Como Arendt observou, conforme mencionado anteriormente, a rejeição a todos os partidos tradicionais é terreno fértil para o totalitarismo; paralelamente, também está claro que o PT, particularmente, encarnou o papel de out-group, de inimigo a ser destruído, passionalmente apontado como culpado por todos os males. O modo de lidar com o suposto responsável pela degradação de um imaginado passado virtuoso é o seu enfrentamento violento, antecipando-se aos supostos riscos que este ofereceria. Como Carone (2002) observou em seu trabalho sobre os frankfurtianos, a agressividade aparece sob o disfarce da autodefesa.

A intolerância se mostrou com um início de conflito contra um ativista, que, utilizando um megafone, denominou-se defensor da democracia; ao ser oprimido e ameaçado pelos presentes, foi logo depois retirado à força pela polícia militar. Com evidente falta de entendimento sobre conceitos políticos, alguns se recusavam a aceitar que o país se tornasse "soviético" ou "bolivariano", opondo-se ao comunismo, defendendo o liberalismo (em cartazes, diziam: "Menos Marx, mais Mises"; “Liberdade, Fraternidade e Honestidade") e ressaltando o medo de viver num país governado por "terroristas": para estes mais extremistas, a solução era a intervenção militar, por vezes qualificada como "constitucional".

O perfil desses manifestantes, de acordo com a pesquisa do Datafolha, era majoritariamente o de indivíduos do sexo masculino (56\% de homens e $44 \%$ de mulheres), com uma média de $45 \operatorname{anos}^{5}$ (30\% entre 36 a 50 anos e $41 \%$ com mais de 51 anos), em sua maioria (77\% deles) com Ensino Superior completo, além de renda elevada: $24 \%$ entre 5 a 10 salários mínimos (SM), 25\% entre 10 e 20 SM e 16\% com mais de 20 SM.

Os atos realizados no período não foram todos de repúdio ao governo. No dia 13 de maio de 2015, cerca de 174 mil pessoas nos estados de São Paulo, Rio de Janeiro, Bahia, Minas Gerais, Paraná, Maranhão, Ceará, Pernambuco, Alagoas, Amazonas, Mato Grosso do Sul, Mato Grosso, Goiânia, Rio Grande do Sul, Sergipe, Santa Catarina, Tocantins, Rio Grande do Norte, Pará e Piauí, além do Distrito Federal, foram às ruas para se posicionar contra o golpe (a ser dado via processo de impeachment) e contra o fascismo. Esses protestos contavam com a participação e apoio de partidos como PT, PC do B e PSOL, e de movimentos como CUT, MST e UNE. Apesar de defenderem a permanência do governo de Dilma, também criticavam o ajuste fiscal feito por ela, 
reivindicando os direitos dos trabalhadores e as reformas agrária e política. Exaltavam a Petrobras como ferramenta de política estatal e, assim como nas manifestações anteriores, a necessidade de punir os envolvidos na Operação Lava-Jato. Além disso, traziam à mesa pautas pontuais como o plebiscito por uma nova constituinte e a saída de Joaquim Levy do ministério da Fazenda.

Os protestos do dia 15 de março de 2015, que reuniram cerca de 110 mil pessoas principalmente no Rio de Janeiro, em São Paulo e no Distrito Federal, trouxeram pautas semelhantes àquelas de abril. Vestidos de verde e amarelo, os manifestantes se apresentavam dispostos a "salvar" o Brasil da corrupção e/ou do "comunismo" e do "terrorismo": a saída da presidenta era sua pauta principal, juntamente com a saída do PT em geral. Para alguns, a solução seria o impeachment; para outros, a renúncia, ou uma reforma política com a implantação do parlamentarismo, ou até mesmo a intervenção militar (opção apoiada, desta vez, com maior intensidade do que nos protestos anteriores). Reivindicavam também maior investimento na educação e a "meritocracia". Como Carone (2002) observou, os inimigos apontados pelos fascistas são qualificados frequentemente como "parasitas da economia".

A intolerância se fazia mais presente nos atos, pois qualquer encontro com pessoas de vermelho ou que faziam alguma referência à defesa de Dilma, Lula, ou PT motivava reação hostil dos participantes da manifestação, que as reprimiam ou ameaçavam. Segundo a pesquisa do Datafolha, o perfil seguia praticamente o mesmo de abril: um ato com uma maior parcela de homens (63\%), onde $37 \%$ tinham entre 36 a 50 anos; $21 \%$ tinham mais de 51 anos; $76 \%$ possuíam o ensino superior completo e eram prioritariamente de classe média ou alta ( $27 \%$ ganham de 5 a 10 salários mínimos; $22 \%$ ganham de 10 a 20 e $19 \%$ recebem mais de 20 ).

São Paulo, no dia 16 de agosto de 2015, juntou 135 mil pessoas com alguns dos mesmos objetivos de abril e maio. A defesa do liberalismo e da meritocracia estava em toda parte, opondo-se ferrenhamente às políticas sociais institucionalizadas no governo petista. Em função da quantidade de tempo em que o partido estava no poder e das políticas sociais, muitos lá presentes caracterizavam o muito moderado e democrático governo como uma "ditadura comunista". Existiam aqueles que não concordavam com o impeachment por tampouco confiarem em qualquer dos nomes sucessores do Executivo e pediam pela renúncia de Dilma; outros, mais extremistas, acreditavam que apenas as Forças Armadas seriam capazes de acabar com o "terrorismo de Estado implantado pelo PT". Alguns cartazes demandavam o fim do Foro de São Paulo, que, segundo acreditavam alguns manifestantes, era o meio pelo qual o partido do governo negociava com países como Cuba, Venezuela e Bolívia, mantendo laços que poderiam trazer influências consideradas negativas para o Brasil. Bandeira histórica do PSDB, a implantação do parlamentarismo era defendida por parte dos manifestantes.

Havia também uma grande demanda pela punição de políticos como Eduardo Cunha e Renan Calheiros e até mesmo cartazes que pediam pela pena de morte para 
corruptos. Alguns manifestantes cobravam, ainda, mais atitude da oposição partidária ao governo Dilma; outros enalteciam a figura do juiz Sérgio Moro - como dito antes, o deputado Bolsonaro não é o único credenciado a líder do movimento fascista. Pesquisa coordenada por Solano e Ortellado (2015) aponta que o perfil de quem tomou as ruas da capital paulista era: homem (57,3\%), branco (73,6\%), com idade entre 30 e 60 anos $(59,2 \%)$, renda familiar superior a $\mathrm{R} \$ 3.940$ reais $(70,9 \%)$ e alto nível de escolaridade $(65,4 \%)$.

No início do ano de 2016, em 13 de março, os verde-amarelos se juntaram novamente em pelo menos 250 cidades brasileiras, totalizando cerca de 3,3 milhões de pessoas para manifestar apoio à Lava-Jato, repudiar Lula, Dilma e o PT ("comunistas", "bandidos", "corruptos" e "terroristas", segundo eles; é clara a sintonia com a forma como, segundo Carone, os fascistas identificam seus bodes-expiatórios ou out-groups: apresentados como "traidores", "vilões", "arruaceiros" e "assassinos"). Sugeriam as mesmas soluções dos atos pró-golpe do ano anterior, com a inclusão de uma nova opção: o retorno à monarquia. Algumas das peculiaridades foram a exaltação do Judiciário pelas prisões executadas ${ }^{6}$, os pedidos por autonomia para investigação pela Polícia Federal e a forte crença de se estar salvando o país da imoralidade. Apesar de serem a favor do processo de impeachment em sua grande maioria, no entanto, não havia nenhum elogio ou sequer menção ao então vice-presidente Michel Temer nos cartazes (ainda que também autoritário e conservador, Temer é identificado com a ordem estabelecida e com a política institucional, o que é repudiado por esse movimento).

No dia de 17 de abril de 2016, o mesmo em que a votação do impeachment ocorreria na Câmara dos Deputados, dois protestos se deram em diferentes horários no Distrito Federal e nos estados do Acre, Bahia, Paraíba, Pernambuco, Rio de Janeiro, Minas Gerais, Mato Grosso do Sul e São Paulo: pela manhã, os manifestantes se uniram pela preservação da democracia, usando palavras de ordem como "Não vai ter golpe; vai ter luta!", defendendo com isso também os direitos do trabalhador. Na manifestação, partidos como PT, PSOL e PC do B e movimentos como a CUT estavam presentes pacificamente; cartazes enalteciam a figura do ex-presidente Lula e da presidenta Dilma como "guerreira da pátria brasileira" (usavam principalmente adesivos com sua imagem de quando foi presa política na ditadura militar iniciada em 1964).

À tarde, houve outro ato, daqueles que estavam a favor do processo de impeachment ou de outras formas de exclusão da presidenta, como renúncia e novas eleições, o retorno da monarquia ou a intervenção militar. Assim, a divisão de horários foi feita para que não houvesse conflitos entre os dois grupos. Este último exaltava a figura do juiz Sérgio Moro, das Forças Armadas, de Jair Bolsonaro e de outras figuras defensoras da meritocracia e representantes dos conservadores no Brasil.

Era clara a falta de confiança nos partidos políticos na intolerância ao Partido dos Trabalhadores, aos partidos em geral, e a qualquer manifestante ou símbolo que os 
trouxessem a lembrança do considerado "perigo comunista". Mesmo aqueles não tão extremistas avaliavam mal o governo, principalmente por utilizar como carro-chefe de sua gestão a priorização de políticas sociais. As manifestações que se sucederiam depois da votação da Câmara, até a definição do futuro de Dilma, da democracia e do país na votação no Senado, continuaram seguindo as mesmas formas e ideias, até que o golpe fosse efetivado.

\section{Bolsonaro, o candidato a líder fascista}

Pesquisa CNT/MDA de fevereiro de 2017 sobre as intenções de voto para presidente em 2018 colocam Bolsonaro como bem colocado em todas as simulações, aparecendo em segundo lugar nas respostas espontâneas não estimuladas e em terceiro ou quarto, mas dentro da margem de erro da disputa pela passagem para o segundo turno, em todas as demais. Desde a redemocratização nos anos 1980 um candidato com discurso tão reacionário e violento não tinha desempenho tão relevante.

O discurso de Bolsonaro, que vem angariando muitos adeptos, é tipicamente fascista: fortemente ancorado no conservadorismo - ênfase no nacionalismo, na família tradicional e na religião -, com centralidade para a hierarquia e para a manutenção da ordem, com o recurso da violência como seu garantidor. Paralelamente, aqueles que combateram a ditadura militar são apontados como "terroristas" (é recorrente a tática fascista de apontar agressores como vítimas e disfarçar a agressão como autodefesa). Em sessão plenária da Câmara dos Deputados de 9 de dezembro de 2014, Bolsonaro (2014a) apontou o suposto caráter criminoso de Dilma Rousseff (repetiu isso várias outras vezes, inclusive no discurso feito no dia da votação do impeachment) por ela ter participado da luta armada, tendo atuado no sequestro de uma autoridade da ditadura militar e em saques de banco. Acusou-a ainda de, por meio de relações com Cuba e países como Venezuela e Bolívia, tentar "planificar o ideário esquerdista" e "cubanizar" o país, e permitir assim o tráfico de armas e munições, além de dar isenção de visto a milhares cubanos, iranianos e haitianos, "escória do mundo" composta por presidiários e terroristas. Essas acusações se sucedem em tom indignado sem que se articulem logicamente ou se embasem - como afirmado, o discurso fascista prima por mobilizar a emoção dos seguidores e não por racionalidade. Além disso, o patriotismo fascista tende a apontar os out-groups como "homens sem pátria", como traidores da nação, como defensores de interesses estrangeiros, e isso está marcado no discurso de Bolsonaro.

O discurso da moralidade não apenas rejeita as conquistas e lutas do feminismo e do movimento LGBT como também canaliza a ladainha anticorrupção como contraposição entre o suposto purismo outsider representado por ele (mesmo estando em seu sexto mandato parlamentar) e pelos militares que representa, de um lado, e a classe política tradicional, impura e comprometida, de outro: QQuem sou eu na política perto de Serra, Aécio, Alckmin, Marina, Ciro? Ninguém. Sou um deputado que vocês 
chamam de baixo clero. Só que não sou uma coisa antes das eleições e outra depois." (Bolsonaro, 2017).

Como visto, o líder fascista tende a se apresentar como "homem solitário, corajoso e íntegro", que enfrenta o sistema corrupto e degradado e a ameaça representada pelos out-groups. Tende a ser um "homem do povo" e perseguido, e Bolsonaro (2014b) sempre busca usar linguagem direta e informal, sem rodeios ou freios, como alguém que nem faz parte da elite estabelecida, nem se curva a ela. Em entrevista para o site UOL, Bolsonaro (2011) disse que quer "um presidente com autoridade e não um demagogo".

Também próprias do discurso fascista, a idealização de um passado para o qual se quer voltar e o ódio à esquerda, com sua identificação como culpada pelos males do presente, de modo não racional, está claramente presente no discurso dos seguidores de Bolsonaro. Cartazes com "Deus, Pátria, Família” podiam ser vistos no protesto, bem como um que homenageava o dia oficial do golpe de 1964, dizendo "Marcha da família com Deus pela liberdade! Viva 31 de março! 50 anos". Valdir, um dos participantes da manifestação do dia 15 de março de 2015, exclamava "Chega de PT e de esquerda no Brasil! Só servem para enganar a população!". A comparação do grau de corrupção e ordem entre a época da ditadura militar (considerada por eles como a "Revolução de 1964") e o momento pelo qual passavam era frequente entre os discursos dos integrantes daquele ato. A reportagem da TV Folha dois dias depois desse ato evidencia a passionalidade do antipetismo.

A corrupção não seria só o desvio de verba dos cofres públicos, mas também a da moral: honestidade e conservadorismo de costumes caminhariam juntos, e o PT seria tanto corrupto como hostil aos bons costumes, favorecendo a homossexualidade, a anarquia, a permissividade em relação aos criminosos. Os governos petistas teriam, assim, afastado o Brasil de um passado imaginado virtuoso, em que valores familiares, da disciplina, da segurança e da honestidade teriam vigorado, especialmente durante a ditadura militar.

A defesa dos direitos humanos, a propósito, é associada à desordem. “O partido que levou o país de cabeça para baixo", nas palavras de um dos manifestantes, utilizaria a prerrogativa de defesa dos direitos humanos para proteger bandidos, estupradores, vagabundos, marginais, sequestradores e corruptos. É dentro desse contexto que eles acreditam na periculosidade do governo petista, que segundo Carlos Metralha, ex-agente do Dops na ditadura militar que compareceu à manifestação, "querem implantar no Brasil o regime comunista, o terrorismo de Estado". Alexandre Morse, outro manifestante, sugeria a solução: "[...] se os militares fizerem uma limpeza aqui e depois de 90 dias fizerem novas eleições nós vamos ter uma nova chance". Como Carone (2002) havia notado, é própria dos fascistas a "suspeita paranoica" que transforma agressores em agredidos e as vítimas em perigo. Bolsonaro (2014b), por exemplo, ao ser perguntado se quer transformar o Brasil em um país "quase como a Alemanha nazista", ri e responde que não, que era o governo Dilma que queria transformar o 
país em "comunismo", em um "regime cubano". A intolerância dos fascistas fica clara pelo extremismo presente em seus discursos, como este, de um anônimo, em um dos protestos: "Intervenção Militar já! Acabar com todos os partidos políticos do Brasil, fazer uma limpeza geral nesse país! Eu não sou bandido, não sou maconheiro, não tenho medo do Exército".8

É própria do fascismo a ideia de que há interesses hostis à unidade nacional e de que é preciso um líder para reunificar a nação e trazer os bons tempos de volta. Em um dos discursos feitos no carro de som das manifestações, foi possível ouvir uma das acusações ao partido governista, tido como inimigo a ser enfrentado: “O PT há anos vem dividido a nossa sociedade: entre ricos e pobres, negros e brancos. Mas a partir de hoje em diante suas divisões são inúteis, não vão mais separar o povo brasileiro porque estamos demonstrando que somos um só povo, uma só nação!"

Para essas pessoas, programas sociais funcionam como uma tentativa de dividir a sociedade e dar mais privilégios a uns do que a outros, por corromper o ideal de que existe uma igualdade entre os indivíduos. Por isso, em sua visão, os governos Lula e Dilma defendiam políticas que incapacitavam os alunos e os influenciavam negativamente (é o mencionado tema do "parasitismo econômico"). Isso é articulado à ideia de desordem na sociedade, que precisaria de autoridade, e liderança enérgica e não de permissividade:

Hoje mais importante do que o menino saber tabuada é saber se ele vai fazer amor com outro menino no futuro. É o "esculacho" da família brasileira. Um pai não quer chegar em casa e encontrar o filho brincando de boneca por influência da escola. Anteontem no Colégio Pedro II do Rio de Janeiro, tradicional, o diretor, que deve ser gay, decidiu que os uniformes agora, que eram de acordo com as cores, agora podem ser à vontade, e ontem já começou a bagunça ontem lá, de menino usando saia. É uma zona! É um "esculacho"! (Bolsonaro, 2016).

Há uma aversão aos debates mais sofisticados da intelectualidade progressista, do conhecimento humanístico e social produzido nas universidades. A defesa do projeto "Escola sem partido", que entende a educação como algo puramente técnico e acrítico, é consequência disso. $\mathrm{O}$ acumulado conhecimento acadêmico, que rejeita suas teses, é antinatural, coisa de "comunistas, esquerdistas, intelectuais antipatrióticos". A história crítica é chamada por Bolsonaro (2016) de "essa palhaçada da Comissão da Verdade do PT". Na reflexão de Arendt (1998: 383) sobre totalitarismo, ela afirma:

A finalidade das mais variadas e variáveis interpretações era sempre denunciar a história oficial como uma fraude, expor uma esfera de influências secretas das quais a realidade histórica visível, demonstrável e conhecida era apenas uma fachada externa construída com o fim expresso de enganar o povo.

A suposta defesa do conhecimento, no entanto, ainda que esvaziado de qualquer concepção crítica, é utilizada para criticar políticas de esquerda, voltadas para a redução da pobreza. Com forte discurso pautado na "meritocracia", na noção de que o sucesso pessoal depende somente do mérito e capacidades do indivíduo, sem influência de 
terceiros ou mesmo do acaso, Jair Bolsonaro e seus seguidores encontram nas políticas sociais outro motivo de crítica ao governo petista. Estas sustentariam e multiplicariam um problema, maquiando-o com uma política que, além de insuficiente, geraria dependência e faria com que os beneficiados continuassem votando no governo que os provê. Exemplo disso é o Programa Bolsa-Família, o mais lembrado e criticado pelos manifestantes fascistas e pelo deputado federal, cuja opinião é incisiva sobre o assunto:

O conhecimento é que liberta o homem, não essa "pipoca" de Bolsa-Família, que o pessoal gosta de falar para ganhar voto! [...] Temos que colocar na cabeça do povo que o responsável pelo insucesso dele é ele! É você individualmente que é o responsável pelo seu insucesso, não queiram culpar terceiros, como é ensinado nos currículos escolares. [...] Quanto mais imbecis tiverem no Brasil, com um diploma de burro na mão e de Bolsa Família na outra, melhor é pra manipular esse pessoal pra votar neles. Portanto, o combustível hoje em dia do poder, que é o voto, é a ignorância, a destruição dos valores familiares, é essa zona que está aí (Bolsonaro, 2016).

A mesma lógica de que as políticas implementadas pela esquerda no governo dividem a sociedade e ameaçam os valores brasileiros aparece no caso das leis que priorizam dar mais representação à questão da sexualidade, que Bolsonaro nomeia como "ideologia de gênero". Em uma entrevista, Bolsonaro (2014b) compara uma vítima de violência por homofobia a um torcedor do Corinthians que apanha na rua por estar vestido com a camisa do time. Segundo o deputado, se o torcedor não pede uma lei específica para a sua proteção, gays também não deveriam pedir: isto significa que não haveria motivo para tratamento diferenciado se os dois passariam pela mesma situação. Bolsonaro acredita que a homossexualidade é um tipo de comportamento imoral que a educação correta, "sem ideologia" e com autoridade, consegue evitar de forma eficaz.

\section{Considerações fincis}

O Brasil não é mais uma democracia desde o golpe de Estado que tirou prematuramente, sem motivos legítimos, a presidenta eleita popularmente para um mandato de quatro anos, permitindo a ascensão de uma ditadura civil ${ }^{9}$, que impõe em ritmo acelerado uma política extremamente antipopular e reacionária. Isso não faz do governo um regime fascista. O fascismo, entretanto, espalha-se pela sociedade e foi importante na soma de forças para que houvesse base social para respaldar a articulação golpista - a qual, no entanto, foi vertical. O próprio Michel Temer, que assumiu ilegalmente (a despeito da inaceitável chancela por parte do Supremo Tribunal Federal) a Presidência, é repudiado pelos fascistas ${ }^{10}$, em função de se distanciar da identidade idealizada: há inúmeras denúncias de corrupção contra ele e é uma das figuras mais paradigmáticas do mainstream da política tradicional brasileira.

Existe nos anseios da sociedade o espaço para soluções autoritárias de viés personalista e antissistêmico, e a junção de manipulação midiática antiesquerdista e 
antipetista com a inabilidade dos governos petistas de construir hegemonia, no sentido gramsciano do termo e não meramente eleitoral ${ }^{11}$, dá a elas um teor profundamente conservador. A criminalização da política e particularmente da esquerda, o descrédito da representação, o incompetente trabalho dos partidos estabelecidos de levar adiante seus deveres de formação política e mobilização para a participação, e a profunda espetacularização e midiatização dos escândalos são elementos que, somados, permitem que o ovo da serpente fascista tenha sido chocado ainda sem um líder prédeterminado para liderar as massas encantadas rumo ao avanço projeto reacionário.

Há, no entanto, figuras públicas qualificadas para encarnar o papel. As eleições municipais de 2016 mostraram não apenas um fracasso da esquerda como um todo, e do PT em particular, mas também a recorrência do discurso por parte dos candidatos de não serem políticos tradicionais. Dois outros nomes, no entanto, podem ser apontados como os mais promissores para assumir tal papel: o juiz de primeira instância e comandante da Operação Lava-Jato Sérgio Moro e o deputado federal representante dos militares Jair Bolsonaro. Ambos se qualificam por seu antiesquerdismo, criminalização da política, conservadorismo, personalismo, e autoimputado papel de cruzado contra o sistema. Bolsonaro, no entanto, assume de forma muito mais explícita e completa o discurso fascista, além de já estar envolvido na disputa eleitoral, de já ter se lançado pré-candidato a presidente e de estar bem cotado nas pesquisas.

A política brasileira, até pela sinalização dada no rompimento do pacto democrático na destituição de Dilma Rousseff, está menos institucionalizada e, portanto, aberta à influência de mais variáveis. A disputa entre a esquerda moderada e a direita liberal e laica, que levava a deslocamentos não abruptos nas políticas públicas definidas a partir de um jogo repleto de atores de veto, também não corresponde mais à conjuntura nacional. Esta se configura crescentemente como um Estado de exceção e em que outros grupos adquirem maior relevância: a política religiosa e o fascismo. Mesmo se alcançada uma não garantida redemocratização, estes atores não poderão ser ignorados. A esquerda, out-group preferencial dos fascistas brasileiros, além do risco de sofrer agressões e perseguições, tem que lidar com o desafio de disputar uma narrativa e de traçar estratégias que Ihe permitam crescer. Hoje, encolhida, vê uma ditadura civil de direita aprovando um amplo conjunto de cortes de direitos, o fascismo se espalhando, e a política religiosa ameaçando o Estado laico. 


\section{Notas}

${ }^{1}$ O golpe jurídico-parlamentar-midiático, movido por meio de processo de impeachment sem crime de responsabilidade, foi discutido em outros trabalhos, antes e depois de sua concretização (Reis, 2015 e 2016).

${ }^{2}$ A grande mídia, inicialmente contrária às primeiras manifestações de maior vulto de 2013 contra o aumento das passagens de ônibus, mudou o discurso ao perceber potencial para atraí-la para pautas reacionárias. Sua cobertura favorável e permanente dos atos pró-golpe foi fundamental para o expressivo comparecimento. Tal mudança de postura é explorada por Santos, F. (2013). Bolsonaro, por sua vez, tem amplo espaço na mídia hegemônica para defender seu revisionismo histórico, pouco afeito à lógica mas com forte apelo emocional.

${ }^{3}$ Nunca deixou de existir, é claro, mas desde a decadência do integralismo o fascismo não assumia tal relevância na política nacional.

${ }^{4}$ A participação de membros do PT em esquemas de corrupção é óbvia, tal como ocorre em todos os demais partidos com acesso aos postos de poder, mas o protagonismo imputado a ele nas práticas ilícitas destoa da lógica e das evidências, visto que outras agremiações partidárias estão envolvidas em maior número de acusações, de condenações, de cassações e em maior valor especulado de desvios de dinheiro público e subornos. A cobertura enviesada da mídia hegemônica tem papel central nessa imagem pública.

${ }^{5}$ Bastante diferente do perfil dos manifestantes de 2013, jovens em sua maioria (Bringel, 2013).

${ }^{6} \mathrm{O}$ Judiciário tem atuado flexibilizando as leis, abusando de conduções coercitivas sem necessidade e prisões preventivas de longa duração sem julgamento, aplicando e banalizando a teoria do domínio do fato (contrariando a concepção de que todos são inocentes até prova em contrário), conduzindo investigações para punir culpados escolhidos "por convicção" e não para descobrir os culpados por meio de provas. Esse processo está ligado à criminalização da política e a uma relação simbiótica com a mídia, mas também a uma perseguição enviesada do grupo que esteve no governo federal nas presidências petistas.

${ }^{7}$ Em ato contra governo, manifestantes explicam por que foram às ruas. TV Folha, 17 de mar de 2015. Disponível em: <https://www.youtube.com/watch?v=JBrkxiBpCVQ>

${ }^{8}$ \#15M - Na cola da turma da intervenção. Revista Trip, 16 de março de 2015. Disponível em: <https://www. facebook.com/revistatrip/videos/10152760919021238>.

${ }^{9}$ A definição do governo que ascendeu a partir do golpe jurídico-parlamentar de 2016 como uma ditadura não é pacífica nem na academia, nem fora dela. Mesmo nos movimentos e partidos de esquerda há resistência ao uso do termo, preferindo-se eufemismos como "governo golpista" e "ilegítimo". Entendese aqui, no entanto, que o termo "ditadura" é apropriado, e insiste-se na relevância de sua utilização, dado que se trata de governo que que se originou de golpe contra a democracia (mesmo que com a cumplicidade do próprio Judiciário e participação central do Poder Legislativo), para, entre outros objetivos, implementar uma agenda profundamente impopular, de inviável de apoio nas urnas, que havia sido derrotada em seguidas eleições. Ademais, a degradação dos direitos e garantias vai continuamente se agravando, conforme foi denunciado já em Reis (2015). Assim como a ditadura militar inaugurada no golpe de 1964 só encontrou seu auge de repressão anos depois, a partir da promulgação do Ato Institucional n 5, a ditadura civil ora vigente tem aumentado seu caráter de Estado de exceção e não se pode prever quão longe avançará.

${ }^{10}$ Sua impopularidade atingiu 62\% em fevereiro de 2017, segundo pesquisa de opinião do Instituto MDA, e isso se explica tanto por suas políticas contrárias aos direitos adquiridos e pelas suspeitas de corrupção, como por ser associado pela esquerda ao golpe e ao neoliberalismo e, pela direita, ao governo deposto (por mais que tenha atuado ativamente para derrubá-lo).

${ }^{11}$ Nem mesmo uma hegemonia meramente eleitoral foi construída, visto que os setores conservadores permaneceram amplamente majoritários no Congresso Nacional, conseguindo facilmente as maiorias qualificadas necessárias para aprovar o impeachment irregular. 


\section{Referencias}

AMARAL, MARINA (2016). "Jabuti não sobe em árvore: Como o MBL se tornou líder das manifestações pelo impeachment." In: JINKINS, Ivana; DORIA, Kim; CLETO, Murilo (orgs.) (2016). Por que gritamos golpe?: Para entender o impeachment e a crise política no Brasil. São Paulo: Boitempo.

ARENDT, HANNAH (1998). Origens do totalitarismo. São Paulo: Companhia das Letras. BOLSONARO, JAIR (2017). “Não é a imprensa ou o STF que vai falar o limite pra mim, diz Bolsonaro". Folha de São Paulo, 13 mar. Entrevista concedida a Thais Bilenky.

(2016). Jair Bolsonaro responde universitários sobre identidade de gênero e bolsa família. TV Top News, 20 set. Disponível em: <https://www.youtube.com/watch?v=TC0diT95dR0>.

_ (2014a). Discurso na Câmara dos Deputados em 9 de dezembro.

(2014b). Agora é Tarde, 8 de abril. Entrevista concedida a Rafinha Bastos. Disponível em: $<$ https://www.youtube.com/watch?v=DDLKxAdXezM>.

(2011). Os ídolos de Jair Bolsonaro. UOL Mais, 04 abr. Entrevistado por Daniela Paixão. Disponível em: <http://mais.uol.com.br/view/1575mnadmj5c/os-idolos-de-jair-bolsonaro04024E9A3970D0810326>.

BRINGEL, BRENO (2013). Miopias, sentidos e tendências do levante brasileiro de 2013. Insight Inteligência, n. 62, jul, p. 42-51.

CARDOSO, ADALBERTO (2013). As jornadas de junho e a mercantilização da vida coletiva. Insight Inteligência, n. 62, jul, p. 22-30.

CARONE, IRAY (2002). Fascismo on the air: Estudos frankfurtianos sobre o agitador fascista. Lua Nova, n. 55-56, p. 195-217.

COCCO, GIUSEPPE; CAVA, BRUNO (2013). Queremos tudo: as jornadas de junho e a constituição selvagem da multidão. Uninômade Brasil, 25 ago. Disponível em: <http:// uninomade.net/tenda/queremos-tudo-as-jornadas-de-junho-e-a-constituicao-selvagem-damultidao/>.

CUNHA, MAGALI DO NASCIMENTO (2015). Fortalecida, bancada evangélica já influencia até deputados católicos. Rede Brasil Atual, 25 abr. Entrevista concedida a Helder Lima. Disponível em <http://www.redebrasilatual.com.br/politica/2015/04/bancada-evangelica-influencia-atedeputados-catolicos-1215.html>.

Em ato contra governo, manifestantes explicam por que foram às ruas. TV Folha, 17 mar 2015. Disponível em: <https://www.youtube.com/watch?v=JBrkxiBpCVQ>.

KITSCHELT, HERBERT (1994). The Transformation of European Social Democracy. Nova York: Cambridge University Press.

LOSURDO, Domenico (2004a). Towards a Critique of the Category of Totalitarianism. Historical Materialism, v. 12, n. 2, p. 25-55.

(2004b) Democracia ou Bonapartismo: triunfo e decadência do sufrágio universal. Rio de Janeiro: UFRJ; São Paulo: UNESP.

\#15M - Na cola da turma da intervenção. Revista Trip, 16 mar 2015. Disponível em: <https://www. facebook.com/revistatrip/videos/10152760919021238>.

REIS, GUILHERME SIMÕES (2015). Como Morre a Democracia. Breviário de Filosofia Pública, v. 140, p. 97-104. Disponível em: < http://estudoshumeanos.com/2015/12/29/como-morre-ademocracia $>$. 
(2016). O Pós-Golpe: O Que Temer. Revista Escuta, Escuta Especial Conjuntura, 14 jun.

Disponível em: <https://revistaescuta.wordpress.com/2016/06/14/escuta-especial-conjunturao-pos-golpe-o-que-temer>.

(2017). A incessante disputa: as ideologias políticas e o que deve ser feito. In: BATISTA, Cristiane; ECHART MUÑOZ, Enara (orgs.). Teoria e Prática da Política. Curitiba: Appris.

SANTOS, FABIANO (2013). Do protesto ao plebiscito: Uma avaliação crítica da atual conjuntura brasileira. Novos Estudos, n. 96, jul, p. 15-25.

; SZWAKO, JOSÉ (2016). Da ruptura à reconstrução democrática no Brasil. Saúde Debate, v.40, n. especial, dez, p. 114-121.

SANTOS, WANDERLEY GUILHERME DOS (2013). Black blocs: os primos sem máscara. O Cafezinho, 31 out. Disponível em: <www.ocafezinho.com/2013/10/31/os-black-blocs-semmascara-por-wanderley-guilherme>.

SOLANO, ESTHER; ORTELLADO, PABLO (coords.) (2015). Pesquisa com os participantes da manifestação do dia 12 de abril de 2015 sobre confiança no sistema político e fontes de informação. GPOPAI-USP. Disponível em: <https://gpopai.usp.br/pesquisa/120415/>.

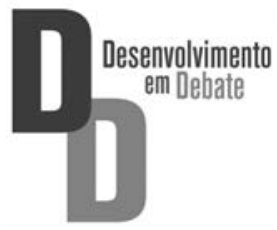

